\title{
Veterans and military masculinity in popular romance fiction
}

\author{
Veronica Kitchen $^{\mathrm{a}}$ \\ ${ }^{a}$ Faculty of Political Science, University of Waterloo, 200 University Avenue West, Waterloo, \\ Ontario, N2L 3G1, Canada
}

5198884567 ext. 32418

vkitchen@uwaterloo.ca

\begin{abstract}
:
Although popular culture has become an important area of study in International Relations, few scholars so far have turned their attention to popular romance fiction, despite an increasing focus on military heroes in these novels. Through an analysis of contemporary category romances featuring military heroes, and combining the scholarship on popular romance fiction with that of security studies, I argue that the structure of the romance genre - which requires the hero and heroine to fall and love and be happy at the end of the novel-reinforces new versions of military masculinity that are friendlier to women, and also subverts the traditional grammar of national security. Further, this structure also necessitates a broad and nuanced view of PTSD that goes beyond violence and instability. The narratives of PTSD studied here transform the experience of re-integration from one of chaos to one of quest to recover as falling in love enables military heroes to come to terms with their combat experiences. However, these new versions of military masculinity are still militarized, and serve to uphold newer versions of militarized masculinity that emphasize resilience and the role of the family in making soldiers battle-ready. Ultimately, the arguments presented here and the research agenda outlined advance scholarship about popular culture and security by including an explicit focus on masculinity, and on popular culture primarily consumed by women.
\end{abstract}

Keywords: Military; masculinity; PTSD; romance; fiction; pop culture

Acknowledgements: I am grateful to Nikita Shah and Vicky Jiang for research assistance.

This is an Accepted Manuscript of an article published by Taylor \& Francis in Critical Military Studies in 2018, available online: https://doi.org/10.1080/23337486.2016.1235761. 
It has now become commonplace for scholars of International Relations to study popular culture as an analogy for understanding world politics (Drezner 2011) or as a phenomenon that might shape our understandings of world politics (Weber 2005; Shepherd 2012). However, as shown by the popularity of articles, books, and panels at conferences on zombies, Harry Potter, Battlestar Galactica, and Game of Thrones, these accounts have tended to be dominated by studies of high fantasy and science fiction, ignoring the genre of popular romance fiction, which forms the largest (13\%) market share of adult fiction sold in the United States (Romance Writers of America n.d.) with unit sales far outpacing those of science fiction and fantasy (Milliot 2015). This omission (but see Jarmakani 2015) is notable for several reasons. First, the popular romance genre is a fruitful site for studying military masculinity, because the genre reflects broader post-9/11 trends in popular culture trends towards a focus on a rugged, practical masculinity of which the soldier hero is exemplary. Second, the form of contemporary popular romance fiction, with its necessary focus on a happy ending, serves to reinforce new forms of hegemonic military masculinity, and also to expose contradictions in the accepted grammar of national security, in which a feminine body is protected, at home, by a masculine soldier who goes abroad.

A romance novel is one where the courtship between the protagonists is the principal driver of the plot, and in which the protagonists achieve a happily ever after (HEA) or a happy for now (HFN) (Vivanco 2013; Regis 2003). Category romances are released by particular pulp publishers with a brand association with romance in the public imagination, such as Harlequin ${ }^{\circledR}$, Avon, and newer publishers such as Carina Press (Kamble 2008, 2). They are published in imprints or lines, often with specific editorial guidelines describing length, tone, characterizations, level of sensuality, and sometimes setting for the story. The popular romance genre is genre is broad, and military heroes are present in many sub-genres. Jayashree Kamble argues that historical, paranormal, and romantic adventure are just as likely to reflect contemporary pre-occupations with war, soldiers, and the military as contemporary romance (Kamble 2012). However, I have limited this study to longerformat contemporary romances from large category romance publishers, ${ }^{1}$ featuring heterosexual

\footnotetext{
${ }^{1}$ Harlequin and its digital-first imprint Carina Press, Random House's digital-only imprint Loveswept, and Penguin's Berkley Sensation.
} 
male characters who have served (or are currently serving) in the military. ${ }^{2}$ I draw conclusions based on extensive reading of these novels. I draw evidence primarily from three novels studied in greater detail, each discussing the experience of a soldier who is dealing with grief and posttraumatic stress: All For You by Jessica Scott, Bring Him Home by Karina Bliss, and Rescue My Heart by Jill Shalvis. Bring Him Home deals with a New Zealand special forces soldier (Bliss 2012a), and the remainder deal with American soldiers who are enlisted or whose rank is not specified. None is portrayed as spectacularly wealthy; these are otherwise ordinary soldiers. One (Jessica Scott's Reza) is a visible minority, though this is not a major plot point. I also draw on evidence from a broader set of contemporary romances that has reached a broad audience, as demonstrated by the fact that it was written by a best-selling author or reviewed on at least one large popular romance fiction blog (Smart Bitches, Trashy Books; Dear Author; or All About Romance). These longer-format novels seek to tell stories that feel true without being strictly factual. The stories are fictional, but all share with the Harlequin ${ }^{\circledR}$ Superromance line the intent to be told in ways that are 'relatable [and] true-to-life...with genuine obstacles that require [the characters] to reexamine what they truly want from life' ("Write for Us: Harlequin Superromance" n.d.). In keeping with contemporary scholarship on popular romance fiction, I do not attempt to draw conclusions about the whole genre, much less all popular romances featuring military heroes (Regis 2011). I do, however, argue that my conclusions are true to the evidence found in the smaller sub-set of contemporary popular romances described here.

Why study soldier narratives in fiction rather than in real life? As scholars of security, studying narrative fiction can give us access to a world we may not otherwise be able to experience. To be sure, there is no shortage of 'herographies' and other soldiers narratives through which we can access the views of soldiers re-integrating into society and their families (Duncanson 2013). But romance novels are more likely to reach a larger audience, and, significantly, an audience that may not be pre-disposed to read soldier memoirs: they have likely picked up the novel because it is a romance, not because it is a book about the military. Scholars of popular romance have shown that readers look to their fiction to learn something, and they expect a certain degree of factual accuracy from the books they read (Radway 1984, 113; Jarmakani 2015). The choice of "true to life"

\footnotetext{
2 The study of military romances featuring women and gay soldiers is an area of future research. They were excluded here because the constraints of space made it impossible to fully examine the somewhat different dynamics of gender and sexuality present in such novels.
} 
category romances heightens the probability that readers may seek to learn something about the military and about security from these books. As such, these novels have the potential, at least, to influence popular conceptions of the military and security.

Scholars of security have also suggested that the study of fiction can provide valuable understanding of security. Christine Sylvester argues, 'the line between fact and fiction can be very thin...in a social networking era, the 'truth' of who someone is and the 'fictions' that a person might send out over cyberspace can be difficult to differentiate; and yet these can figure prominently in that person's job and other social prospects. Today's treasured facts can also become tomorrow's fictions, as knowledge in all areas is updated and revised' (Sylvester 2012, 12). Scholarship on aesthetics and politics remind us that what is political about studies of art (including fiction) is the space between that which is represented and its representation (Bleiker 2009, 8). In literature which is not explicitly political, such as romance novels, we are forced to draw our own ethical and policy conclusions (Bleiker 2009, 13). Fiction is not an escape from reality, as has been argued by some scholars of popular romance (most notably, and controversially, Radway 1984), but rather a mechanism for readers to work through big, resonant social problems (Dawson 1994, 21) - in this case veterans returning from war, and the impact on their lives and families. Studying stories, whether fictional or non-fictional, can help us to understand 'dimensions of security challenges that cannot easily be understood through conventional forms of policy analyses' (Bleiker 2009, 48) and to get empathetic views on everyday life (Bleiker 2009, 39), bearing in mind that 'there is always more than one story to be told' (Wibben 2011, 109) — or, in the case of fiction, more than one story to be read.

Military romance narratives in particular help to construct and reinforce the set of socially acceptable military masculinities in any given time and place (Dawson 1994, 23). While this set of novels spends little time describing the conflicts in which their male protagonists were or are engaged (I discuss the implications of this below), they are all clearly about the post-9/11 conflicts in Iraq and Afghanistan. As such they construct contemporary versions of hegemonic military masculinity. Even without many details of violence and trauma-something that seems to be true of first-person PTSD narratives, like their fictional counterparts (Woolf 2012, 58), popular romance fiction provides a richer description of the personal life and, through the representation of the hero's point of view, inner thoughts of military veterans than most readers would have access 
to through first-hand experience or sources. Because the descriptions of the familiar (such as the setting, language, and relationships) seem accurate, readers are more likely to read descriptions of the unfamiliar as accurate as well (Radway 1984, 195). This heightens the capacity of romance fiction, then, to help to reproduce societal conceptions of military masculinity.

The prevalence of military heroes in contemporary romance novels tracks a broader cultural obsession with military heroes after 9/11. Susan Faludi argues that after 9/11 Americans began a search for heroes who could provide solace through their acts of courage (Faludi 2008, 82). Police officers, firefighters, and, as the invasions of Iraq and Afghanistan began, other men in uniform came to be seen as the best representatives of manliness, contrasting practicality, strength, competence and honour with a 1990s view of masculinity characterized by emotionally sensitivity, cultural awareness, and intellectualism (Faludi 2008, 83-101). The popularity of romance fiction featuring military characters, especially those from the special forces, echoes this broader cultural shift in masculinity. After Navy SEAL Team 6 captured and killed Al Qaida leader Osama bin Laden, popular media linked the appeal of the Navy SEAL as sex symbol to the phenomenon of military heroes in romance novels. Cosmopolitan magazine honed in on the physique, competence, persistence, and ability to keep secrets as part of the Navy SEAL's sex appeal (Ruderman 2011). Annys Shin of The Washington Post argued that part of the appeal of the Navy SEAL hero in romance novels is his competence: as heroines have evolved to become strong, competent women in positions of power, their heroes have had to become more competent as well. Who could be more competent than a Navy Seal? (Shin 2011). Jane Litte, writing on prominent romance blog Dear Author, similarly identifies competence and protection as part of the appeal of the Navy SEAL: 'No matter what the costs, no matter how difficult the effort, no matter what the challenges, and no matter how long it will take... [the Protector Alpha archetype] will take care of you' (Litte 2011).

While popular romance fiction has received significant attention from cultural studies scholars, scholars of world politics, and particularly of security, have yet to turn their attention to this genre. ${ }^{3}$ Doing so, focusing on the portrayal of soldiers with PTSD, highlights the contradictions and tensions in military masculinity illuminated by combining a focus on form and authorship (drawn

\footnotetext{
${ }^{3}$ A very few scholars of popular romance have turned their attention to world politics, notably the characters of the sheikh (Jarmakani 2015) and the soldier (Frantz 2011; Kamble 2012) and their relationship to world politics.
} 
from scholarship on popular romance) with a focus on content (drawn from security studies). While the romance genre, featuring a courtship narrative and a happily ever after, is timeless, commercial popular romance emerges in a particular time and place, associated with pulp publishers in Canada and the United Kingdom, and then ultimately gaining popularity in the United States with many authors identifying the 1970s and 1980s as a period of particular growth (see Vivanco 2011; Regis 2003; Faircloth 2015 for histories of the genre). Through the same period, critical scholarship on popular romance fiction has also evolved from a focus on viewing the genre 'porn for women' and a 'tool of the patriarchy' to more sophisticated studies that classify the genre according to its structure and publishing practices, while acknowledging the diversity and complexity of its content and the potential for readers to find romance empowering and feminist (Regis 2011). Contemporary scholars of popular romance argue that fiction must be understood as more than simply as an "escape" for housewives (Radway 1984, 88) or as a tool for teaching them to be satisfied with housework or the centrality of men's roles in their lives (Dubino 1993, 108). Rather, a more sophisticated reading of popular romance fiction acknowledges that

while sometimes committing the patriarchy-reinforcing crimes the critics accuse it of, much more often reinforces a sense of self-worth in readers while reflecting a psychologically accurate portrayal of their lives. It does this by demonstrating the idea of women as strong, active human beings; by reinforcing the validity of their preoccupations; and by putting them at the center of their own stories, empowering them by showing heroines who realistically take control of their own lives (Crusie 1997).

Similarly, among scholars of security who study fiction, reading fiction is not an escape from reality, but rather a way for us to engage with and work through the emotions, circumstances, and conflicts of everyday life (Dawson 1994, 20). Contra Radway's conclusions in the 1980s, popular romance fiction is a way of viewing human activity in a new light (Radway 1984, 197)

Taking into account the particular structure of the popular romance genre is also important because in this case, the form of a romance novel carries a political message, much as Bleiker argues that the sound of music can carry a message (Bleiker 2009, 60). By studying the relationship between the form and content of popular romance fiction featuring military heroes, we can understand the explicit and less explicit politics behind them. First, even seemingly depoliticized portrayals of military heroes reflect versions of military masculinity that, on the surface at least, are more 
favourable to women. Because popular romance fiction is necessarily a courtship narrative, it most often takes place on the homefront, away from the field of battle. The prescribed happily-everafter ending means that the hero must be loveable (by the heroine), otherwise it is not a popular romance (Regis 2003; Wendell and Tan 2009). This characteristic form enables a shift in the portrayal of military masculinity that subverts the grammar of national security, in which a masculine soldier fights abroad to protect a feminine figure at home (Hoganson 2000; Elshtain 1987). However, on deeper inspection, it becomes clear that these are still hegemonic masculinities, and, as will be shown below, militarized. Second, looking at post-combat novels featuring soldiers struggling with mental health issues illustrates a different relationship between form and content. Again, because the hero and heroine must ultimately fall in love, the portrayal of heroes with PTSD must be presented as masculine-emphasizing the hero's quest for control over his body and mind. This portrayal of military masculinity has a darker side, as it also reinforces cultural perceptions about the appropriate role of the spouse and the family in maintaining soldier mental health.

\section{New hegemonic masculinities and the subversion of the grammar of national security}

Hegemonic masculinity is hegemonic in the Gramscian sense; it is the "currently most honoured way of being a man' and, as such, can change over time (Connell and Messerschmidt 2005, 832). Romance heroes consistently embody a 'spectacular representation of masculinity' characterized by muscularity, strength, virility and professional status (Allan 2016, 25, 29). This helps to explain the prevalence of special forces soldiers (Chelton 2015), and the fact that even enlisted soldiers are seen to be exemplary leaders; the best possible embodiment of their rank. They are alpha heroes: 'strong, dominating, confident men, often isolated, who hold a tortured, tender element within themselves that they rarely let anyone see' (Wendell and Tan 2009, 77). More specifically, the romanticized soldier and Navy SEAL are the perfect exemplar of the Protector Alpha archetype: capable, trustworthy, and honourable; a man who 'knows you are capable of doing everything but they are willing to "take care of things" once you give them the go ahead and then able [to follow] through and accomplish whatever task is set before them' (Litte 2011).

Often, the fact that the hero in a military romance is a veteran is incidental to the story in popular romance fiction, and does not drive the narrative (see, for instance Shalvis 2014; Knox 2013; Higgins 2013; Carr 2012). Generally, the romance between the returned military hero and the 
heroine is a new one with a focus on the courtship phase; in most cases, the couple do not have to deal with the pressures of a deployment (but see Jessica Scott's Back to You (Scott 2014b)), which deals with a couple whose marriage has been destroyed by too many deployments). In other cases, the fact of being a veteran is more important to characterization. In Shalvis's Rumor Has It, Griffin is portrayed as having had a head injury, but aside from one incident where he has a severe migraine (Shalvis 2013) and a few mentions of his scar, making Grif a soldier is most often used as a convenient way to explain why he and the heroine have been separated for so long.

On the surface, military masculinity does very little work in these novels. However, as some commenters from both popular romance studies and security studies have noted, that which does not immediately engage politics is not apolitical (Barry 2013; Vivanco 2016; Bleiker 2009). Military romances, according to Jayashree Kamble, inherently critique 'American patriotic aggression' (153) because by showing the soldier home from war, they argue that 'the American soldier's right to a long, happy marriage' takes precedence over his patriotic duty' (Kamble 2012, 154). This holds true particularly for soldiers who have left the armed services by the time of their romance. However, military romances also have a broader political significance related to the structure of the romance genre-which must end with a happily ever after or happy for now: the romantic military hero must be presented as someone the heroine can fall in love with. These men are often portrayed as being kind to animals (Shalvis 2012) and children (Shalvis 2013) and as good, caring leaders who would do anything for his subordinates (Bliss 2012b, 11-15). This romanticized military masculinity shares characteristics with 'New Man' versions of military masculinity, in which soldiers are seen to be 'tough-but-tender-intelligent, sophisticated, humane and compassionate, discriminate in the use of force, but convincing warriors when required' (Duncanson 2013, 60). These newer versions of military masculinity are arguably more favourable to women, as they temper the primacy of aggressiveness and unquestioning violence that has typically been connected to sexual and intimate partner violence (Baaz and Stern 2009; Higate 2012). As I will show later, though, the portrayals of these emergent hegemonic masculinities in popular romance fiction may have other effects on military families.

As Duncanson argues, however, these new, softer versions of military masculinity are not unproblematic, as they still rely on 'the construction of those in areas of conflict as primitive, inherently and excessively violent and barbaric, or as helpless victims' $(2013,61)$. Interestingly, 
romances featuring veterans are often characterized by a general failure to construct an image of war experience abroad at all. The military experience of the heroes is rarely described explicitly, or only in flashbacks or nightmares. These are usually to experiences where the soldier is in peril, or watching someone he should be rescuing in peril. For instance, Richland's Rey has flashbacks to rescuing a child in an incident that left him a double amputee when a mine exploded (Richland 2014), and Jessica Scott's Reza reflects on the difficult decisions he had to make between killing the enemy and protecting his own men (Scott 2014a, 86). By avoiding descriptions of the 'Other' or presenting the 'Other' in only very limited ways and by portraying foreign soldiers as necessary rescuers or victims of aggression (Reza, for instance, describes 'an enemy that would drag your carcass through the streets if you lowered your guard' (Scott 2014a, 68), and Shalvis's Adam 'lost half his unit because of bad intel' (Shalvis 2012,113). These portrayals of military masculinity also serve to reinforce uncritical notions of Western interventions. As in contemporary romances featuring sheikh heroes, the absence of politics serves to reinforce American (or more broadly Western) exceptionalism (Jarmakani 2015, 22-24). Without descriptions of the Other or the battlefield, the reader is never prompted to think about the agency (or lack thereof) of the enemy or victims of American or allied attacks. The portrayal remains one-sided and does little to inform readers about Western intervention in a broader context.

However, the same dynamic of focusing on veterans on the homefront (including on-base life in the United States) actually subverts a traditional grammar of national security where the woman left at home is to be protected by a masculine figure who fights abroad. In this set of novels, the subversion happens not because of the portrayal of women who fight in wars ${ }^{4}$ (as in Elshtain 1987; Sjoberg and Gentry 2007), nor because of the portrayal of threats to the homefront (Bigo 2006), which remain undescribed, but rather because the focus on the homefront shows definitively that women cannot be protected from the dangers of war and violence. Of course, this conclusion, and the dissolution of boundaries between the domestic and the foreign, is hardly novel to feminist scholars. Just as the portrayal of women soldiers makes clear the contradictions in the narrative of the male protector and the female to be protected (Kronsell 2006, 120), so too does the focus on men who have been irrevocably damaged by war and women who cannot be protected from its scars. As the masculine military heroes accept that they cannot be protectors, these romance novels

\footnotetext{
${ }^{4}$ Women soldiers certainly appear in romance fiction, but are a topic for another article.
} 
further reinforce a masculinity that is vulnerable and maintains a more equal balance between masculine and feminine roles. I illustrate this through a discussion of two relationships: that between Reza and Emily in Jessica Scott's All For You (2014a) and that between Nate and Claire in Karina Bliss's Bring Him Home (Bliss 2012b), the third book in her SAS (New Zealand special forces) Quartet.

Reza Iaconelli, the Arab-Italian-American hero in Jessica Scott's All For You has become an alcoholic as a result of his combat experiences (Scott 2014a). The heroine is Emily, a psychologist and officer new to the army, who has no combat experience. As such, she stands in for the civilian left behind while the masculine soldier fights abroad. Their romance takes place against the backdrop of Reza's alcoholism, a hazing scandal, a rash of suicides on the base, and the PTSD affecting two of Reza's young soldiers. As with Scott's other books, the portrayal of the US army as an institution is unflattering. The protagonists and their friends are portrayed as good people trying to do right in a system that is failing them. Reza displays a desire typical of alpha romance heroes to protect Emily from the realities of war (Scott 2014a, 103, 195). He undertakes instead to train her and guide her through the ways of military life (Scott 2014a, 104). This is still born of a desire to protect, but it becomes quickly clear that even without Emily being exposed to combat, Reza cannot protect her from the violence of war. Emily overlooks a soldier from Reza's unit who turns out to have PTSD, who later dramatically commits suicide in front of the hospital (Scott 2014a, 169-170). Emily's psychological assessment of the soldier leads to his discharge from the army, and ultimately his suicide. Like Reza, Emily has failed her men. Reza notes that 'she'd descended into the blood and mud and her uniform now bore the dirty stains of war' (Scott 2014a, 196).

Like Reza, Nate, the hero in Karina Bliss's third SAS book, Bring Him Home (Bliss 2012b), tries to protect the heroine without success. At the beginning of the book, Nate returns to New Zealand to handle some business matters, but refuses to connect with any of his friends except Claire, the widow of his friend Steve who died in an IED attack on their last tour of duty. As Nate and Claire become attracted to each other, it is clear that Claire is further along in the grieving process than Nate is. Not only does Nate suffer nightmares and guilt, he thinks he is a coward for not having saved both Steve and Ross, another friend and fellow SAS soldier: 'a hero would have found a way to save both' (Bliss 2012a, 37). He transfers his feelings of protection from Steve to Claire- 
but he cannot save her any more than he could save his comrade (Bliss 2012a, 60). Nate still harbours the secret that is alienating him from his loved ones: not only did he leave Steve trapped in the wreckage of their vehicle (on Steve's orders), he shot him when the vehicle caught fire in order to spare him a slow, agonizing death. While he is plagued by guilt over leaving Steve, he does not regret his decision to shoot his friend. For most of the book, Nate seeks to protect Claire from the true cause of her husband's death, and from presenting Steve in anything less than the most flattering light (Bliss 2012a, 80). He makes it his mission to tell Claire, who is angry at Steve for going on another tour and for dying, stories that will make her love her husband again (Bliss 2012a, 70, 128). But Claire has already experienced the worst that war could bring - the death of a spouse - and is ready to move on. In order for Nate to move on with his life, that is, fall in love with Claire, he must stop protecting her from the realities of war and allow her to make her own choices. When he finally tells her the truth about her husband's death, Claire is shocked and repulsed. But ultimately, her biggest concern is that she will not be able to get past what Nate has done to continue their love affair (Bliss 2012a, 214). Forgiving Nate is ultimately about accepting the emotional complexity of war. As Nate reminds her, in both her relationships with Steve and with him, 'the good feelings are tangled up with the bad feelings' (Bliss 2012a, 62, 217).

In both romances, the relationship turns on the hero recognizing the agency of the heroine. Emily and Claire women who do not participate in combat, but are not separate from the effects of war. Neither book goes so far as to make women active participants in combat, but they are active participants in the experience of war: Emily through her work as a psychologist with a direct impact on the life and health of her fellow soldiers; Claire through her relationship with two soldiers, first Steve and then Nate. The portrayal of strong femininities is accompanied by a portrayal of masculine figures who recognize this strength and agency. The heroine remains in control, allowing the Protector to engage in his caretaking (Litte 2011), and in doing so she tames the dangerous hero and 'forces him to acknowledge her power as a woman' (Regis 2003, 171). The masculinity portrayed, then, is more favourable to women because it allows women to be in control of their own lives. Through this subversion of the stereotype of the woman left behind to be protected, these popular romances both provide insight into military life, but also serve to construct masculinities that recognize masculine weakness and facilitate feminine agency. Even on the homefront, women cannot be protected (nor do they need to be) and men are forced to accept the limits of their control over self and others. 


\section{Reconstructing military masculinity: PTSD and disability in military romance novels}

The portrayal of masculine heroes who have suffered physical and more often psychological injuries is more subversive. The military hero with a combat-induced disability is a combination of Jayne-Ann Krentz's 'dangerous man' and 'sentimental' heroes. The 'dangerous man' must be tamed by the heroine, forcing him to 'acknowledge her power as a woman,' and the 'sentimental' hero must be healed by the heroine. As Pamela Regis argues, 'the injured, dangerous hero who is both healed and tamed by the heroine is doubly powerful at the center of a romance' (Regis 2003). This helps to explain the popularity of romance novels with heroes with post-traumatic stress disorders, physical difficulties, or other issues that challenge their re-integration into society. Some scholars of popular romance fiction have argued that contemporary (post 9/11) romance novels portray post-traumatic stress disorder in inaccurate ways, and notably, as being cured by the heroine's love (Holden and Tabol 2015). Kamble argues that the romance novel hero with PTSD critiques military violence by discussing the toll it takes on soldiers (Kamble 2012, 155). I reject Holden and Tabol's argument and extend Kamble's by arguing that the portrayal of post-traumatic stress disorder helps to reinforce new hegemonic portrayals of military masculinity, but may also serve to reinforce new expectations of resilience and family involvement in soldier health.

Returned soldiers face contradictions between the heroism narratives and PTSD narratives they encounter as they return home (Woolf 2012). Military heroes are often presented as worthy of exalted social status because of their service (Woolf 2012, 9); this is reflected in the portrayal of alpha masculine heroes in romance fiction. However, the PTSD narratives of soldiers themselves may contradict the narrative of privileged social status (Woolf 2012), with everyone but the soldier recognizing his heroism, often because of the horrible things they have seen or done. Nate, for instance, clearly states that he 'couldn't live with [Claire] seeing him as worthy' (Bliss 2012a, 128). His friend Lee, initially thought dead but revealed in the fourth book of the SAS Quartet to have been held by the Taliban, does not want to be treated as a hero when all he did was survive 'even when [he] didn't want to' (Bliss 2013, 216, 227). Reza describes himself as 'a beast who'd lost his compassion somewhere on the road to Baghdad' (Scott 2014a, 53). Popular romance fiction can give those who do not have first-hand experience with soldiering or with PTSD — those who read popular romance fiction in part to learn something (Radway 1984, 113) —more complex ways to think about PTSD. They also construct a hegemonic masculinity that includes men with 
post-traumatic stress disorder, countering earlier research that suggested that men with PTSD were feminized (Whitworth 2008). As discussed above, the hero in a romance novel must be a 'spectacular representation of masculinity' (Allan 2016, 25); any description of him necessarily reinforces this masculinity. Finally, popular romance fiction helps to reconcile heroic discourses with PTSD discourses, and in doing so further reconstructs the hegemonic masculinity that includes PTSD. This masculinity, however, ultimately has profound implications for the role of military families, which are reinforced in these novels.

Popular romance fiction featuring military heroes personalizes the post-combat experience by presenting varied true-to-life ways of dealing with the stress of combat and re-integration (Finley 2011). Adam, the hero in Jill Shalvis's Rescue My Heart, has been struggling with post-traumatic stress for two years at the opening of the novel (Shalvis 2012). However, it still plays a significant role in his life: on the second page of the novel, Adam takes note of his mental state, noting 'the PTSD had been kicked down to a lowly 3 on the scale, when two years ago it would've been at a 10.5 , not to mention wholly consuming him' (Shalvis 2012). He recognizes that working through his PTSD is an ongoing process, and repeatedly refers to techniques he uses to manage his stress: deep breathing (80), anger therapy, both official and unofficial $(97,172)$, letting go of control (101), not sitting on guilt (113), having a plan and moving on it (126), and talking about his fears (140). Richland's Rey has nightmares, but his double amputation and aphasia are much more pressing needs (Richland 2014). Scott's Trent in Back to You repeatedly insists that he does not have PTSD $(2014 \mathrm{~b}, 114,150)$ but displays profound alienation from his wife and fear that he will lose his temper and hurt his children $(121,133)$. Ford Hendrix's military service in Susan Mallery's Three Little Words plays almost no role in the story (Mallery 2013). But Ford displays hypervigilance, moving out of his mother's house because 'he' $d$ awakened more than once to find his mother hovering. What she couldn't possibly know was that with his military training, he didn't react well to people hovering while he slept. Sneaking around like that was a good way to get dead' (20). Ford is presented as detached, and he notes that he has had difficulty re-adjusting to civilian life (44). 'Things happened when I was gone. I had to go to hard places and deal with tough situations' (73). When asked if he needs help or therapy, he merely laughs and answers 'I already did' (74). Later, when pressed, he notes: 'I did things, saw things. They're ugly and I don't want you to think about that stuff.' Then: 'I was debriefed. I saw a navy shrink because it was required. I'm done... It's the monster under the stairs. Eventually it starves to death.' (172). 
In each case, however, the hero's appeal is still presented as related to the protector alpha characteristics exemplified by his military career. Reza is described as a beautiful 'warrior god' (Scott 2014a, 12), and Rey is 'confident and strong... attractive at the same time as dangerous' (Richland 2014). In Rescue My Heart (Shalvis 2012) Holly, the heroine, asks Adam to help her find her missing father. Adam follows his trail into a cave for Holly, despite the fact that caves trigger his anxiety attacks. Holly recognizes that this is part of what attracts her to Adam: 'I needed help finding my dad. And did you say you couldn't be bothered? No. You were willing to do whatever it took. You were injured and exhausted, and you still dropped your own work and responsibilities and took me all over hell and back. You were, are, the one man I can trust. With anything.' (226). She makes it clear that she does not view his PTSD as a barrier: She tells him 'You're not mentally ill, Adam, you're human' and notes that 'it was hard to watch a big, bad, tough man like Adam fall apart and put himself back together again without wanting to hug him' (141-142). Midway through the novel, Adam is not ready to hear her reassurances; he has not himself recognized that he is still sufficiently masculine to be worthy of love: he responds 'No, I'm not up for that level of blind trust' (226). By the end of the novel, however, Adam has recognized that Holly loves him even though she has seen him when his PTSD is at its worst (227). Her love does not heal him, but by the end he doesn't 'give a flying fuck about being weak' (284). It is this recognition that PTSD will not necessarily go away combined with the structural necessity that a romance novel must finish with a happily ever after or happy for now that allows the reader to see Adam as ill, but still masculine.

Where PTSD is a significant plot point in the military romances studied here, the heroes, including Adam, Lee, Reza, and Nate already discussed, narrate their PTSD through chaos and affront to their masculinity. When individuals talk about how illness affects their bodies and minds, they create a narrative about that illness. The narrative 'gives voice to an experience that medicine cannot describe' as embodied in a particular person, but also as a social experience, because the narrative is made possible by modern medical language and diagnostics (Frank 2013). As Arthur W. Frank notes, 'a published narrative of the illness is not the illness itself, but it can become the experience of the illness' (Frank 2013, 22). If we accept that fictional narratives can shape social narratives as much as 'real life' narratives, then the narratives of PTSD in romance novels have the potential to shape how we view PTSD in society. Romance novels accomplish this by turning chaos narratives of PTSD into quest narratives of PTSD. 
Woolf's research shows that most first person accounts of PTSD and re-integration are characterized by the chaos narrative of illness described by Frank (Woolf 2012, 51). In the chaos narrative, there seems to be no possibility of a return to health (but rather the eternal possibility of being 'sucked under') and 'the modernist bulwark of remedy, progress, and professionalism cracks to reveal vulnerability, futility, and impotence' (Frank 2013, 97). There is little order to the narrative, and in Woolf's research, a strong sense of abandonment by American society, which sees those with PTSD as unrepresentative of the heroes they expect (Woolf 2012, 56). Fox and Pease associate these narratives of chaos with the failure of traditional masculinity, which is associated with 'independence and self-sufficiency; of mastery over one's body and external objects' (Fox and Pease 2012, 20). This is particularly true in military training where emphasizing masculine traits and celebrating this control is key to success (Fox and Pease 2012, 21).

Quest narratives, by contrast, are characterized by 'meeting the suffering head on; they accept illness and seek to use it' (Frank 2013, 115). Narrating PTSD as a 'trauma that one could not expect anyone to stoically absorb' places it outside the soldier and therefore not an affront to his masculinity (Fox and Pease 2012, 22). This is how Consuelo, Ford's colleague and fellow veteran, understands his detachment and her own, attributing it to the 'ragged edge' of military service: 'No one can go through what Ford did and remain unaffected. War leaves scars. Some are on the inside and some are on the outside, but we all have them. Ford's basically a good guy, but he's still dealing' (169). Similarly, in Jessica Scott's All for You, the plot centres on how base authorities deal with two soldiers claiming PTSD. One has no combat experience, and is therefore seen as cowardly by his peers and superiors. He is repeatedly referred to in child-like terms by others (4, $9,10,13)$, at least until it is revealed he has been subjected to illegal military hazing. The other was a combat veteran of several tours, a good soldier who Reza is convinced has PTSD, who ends up addicted to crystal meth. He eventually commits suicide while Reza is trying to help him. Here again, the external explanation for PTSD is seen to be more masculine.

Reza's own conflict-related trauma manifests in his alcoholism. The experience of seeing his soldier commit suicide leads Reza, who had been one month sober, to begin drinking again. Emily tells Reza she wants to be with him, but not unless he addresses his alcoholism in an in-patient rehabilitation program. At some risk to his career, given the portrayal of the army's (lack of) support for soldiers experiencing mental health problems as a result of deployment, Reza asks to 
be sent to one. The story ends with a happy for now, but it is made clear that Reza knows he still has a great deal of recovering to do: Emily is a supporter, but her love alone cannot heal Reza. His chaos has become a quest to heal himself. Similarly, Karina Bliss's Lee is alienated from his fiancée Jules on his release from captivity. His friends convince Lee that he needs to go through the process of grieving their lost years with Jules (235). Jules's love does not heal him, but it does help him to come to terms with his need for help: 'Lee could no longer pretend Jules's love was enough to make him magically A-frickin'-okay. Or make the difficulty he was having connecting with others everybody else's fault. The fault was his' (220). Contra Holden \& Tabol, these novels do not suggest that PTSD can be cured by romantic love (2015). Rather, the structure of the romance novel and its courtship narrative reinforces a transformation of the PTSD narrative from chaos to quest, thus reinscribing the hero's masculinity and allowing him to heal himself.

The quest narrative of PTSD represented in these romance novels engages a model of military masculinity quite different from that of the ultra-competent alpha male so often seen in romance novels. The military man who dealing with his PTSD or combat stress — not consumed by it — is a competent alpha worthy of falling in love with. Neither he, nor his illness, threatens the romantic heroine, nor does it threaten the masculinity of the hero. In transforming the narrative from chaos to quest, the military hero restores — or at least begins to restore — order to his life and control over his body, popular romance fiction reinforces a new hegemonic military masculinity. This new version of military masculinity, however, is still a profoundly militarized masculinity. That is, it contributes to the ordering of society for military readiness. As Allison Howell has shown, recent narratives of PTSD as problems of mental health put forth by the Canadian and American militaries are consistent with a quest narrative. Soldiers with PTSD are to overcome their combat stress through self-improvement in order to return them to combat readiness $(2011,107)$. In the United States Army, and increasingly in other militaries as well, there is an explicit focus on family readiness as opposed to simply soldier readiness (Jauregui 2015, 467). In Howell's account, military approaches to the treatment of PTSD through resilience rely heavily on soldier's wives and families as resources for maintaining the mental health of their soldiers $(2011,126)$. As Howell argues, medicalizing the trauma experienced by soldiers is a way of not politicizing it: trauma is to be address through overcoming PTSD (as in popular romance's PTSD quest narratives), not through critique of the mission itself $(2011,138)$. Such programs carry with them the implicit message that war is inevitable, so no one in society can be a burden (Jauregui 2015, 471). Indeed, 
while the popular romance authors studied here critique war in general, there are no cases where the specific missions (usually in Iraq or Afghanistan) are criticized. Even Jessica Scott's novels, which are highly critical of the American military, avoid direct criticism of American foreign policy (Scott 2014a).

This means that while romance writers writing military heroes inscribe "new man" (Duncanson 2013) versions of masculinity less threatening to women, they are also versions of masculinity that fail to subvert gender roles (Potter 2008, 8). So while popular romance fiction inherently criticizes war by portraying the soldier's love life as equal to, or more important than, his duty to country (Kamble 2012), it also serves the function of reinforcing new modes of masculinity that uphold a particular order focused on military readiness. However, the new order does subvert the old grammar of national security. By reinforcing a model in which an intimate partner and family are key to restoring and maintaining soldier health, the distinctions between combatant and protected begin to be erased. The family is absorbed into the military structure rather than being the thing to be protected.

\section{Conclusion}

The value of studying contemporary popular romance fiction to understand security is not simply because the stories recounted reflect real life, although they do. More importantly, these stories, through their broad reach and through stories that seem true (although they are fictional), construct and reconstruct a particular society. In the novels studied here, the narratives reflect and reinforce a new hegemonic masculinity in which heroic men are vulnerable, and maintain their hegemonic masculinity even in face of post-traumatic stress disorder. They also work to subvert the accepted grammar of national security by showing that women at home cannot be protected, and may even be drawn into the military apparatus through a focus on the family in military readiness. Drawing on insights from scholarship on popular romance fiction shows how these effects are in part a product of the structure of popular romance fiction. Further research drawing on the synergies between popular romance fiction could include studies of military heroes (including gay and female soldiers) in other sub-genres of popular romance (for instance, historical romance, romantic suspense, or new adult), or could move beyond the military context, building on work like Amira Jarmakani's on sheikhs in popular romance (Jarmakani 2015) to examine other aspects of world politics and security. Finally, the fact that popular romance fiction is a genre written and read by 
women, who have often been stigmatized for what they read and write (Lois and Gregson 2015), suggests that there is room to study the gender identity of authors and how it shapes their writing (Frantz 2002). In the case where authors are military veterans themselves, as are both Scott and Richland studied here (Scott 2016; Altman 2016), this could link to the security studies research methods of autoethnography as a way of understanding structures of power and politics (Brigg and Bleiker 2010), and fiction writing as a way of working through problems where there is lack of information (Park-Kang 2014). In each case, one could compare portrayals of military life in popular romance fiction to portrayals in other popular culture mediums, such as film or television, to determine how the effects of the structure of the narrative work in these mediums. ${ }^{5}$ Ultimately, the arguments presented here and the research agenda outlined advance scholarship about popular culture and security by including an explicit focus on masculinity, and on popular culture primarily consumed by women.

\section{References}

Allan, Jonathan A. 2016. "The Purity of His Maleness Masculinity in Popular Romance Novels.” The Journal of Men's Studies 24 (1): 24-41. doi:10.1177/1060826515624382.

Altman, Jennifer. 2016. “Not Your Grandma’s Romance.” Princeton Alumni Weekly. January 27. http://paw.princeton.edu/article/not-your-grandma\%E2\%80\%99s-romance.

Baaz, Maria Eriksson, and Maria Stern. 2009. "Why Do Soldiers Rape? Masculinity, Violence, and Sexuality in the Armed Forces in the Congo (DRC)." International Studies Quarterly 53 (2): 495-518. doi:10.1111/j.1468-2478.2009.00543.x.

Barry, Emma. 2013. "Politics and the Romance Novel." Emma Barry - Author Blog. May 28. http://authoremmabarry.com/2013/05/28/politics-and-the-romance-novel/.

Bigo, Didier. 2006. "Internal and External Aspects of Security.” European Security 15 (4): 385404.

Bleiker, Ronald. 2009. Aesthetics and World Politics. 2009 edition. Basingstoke: Palgrave Macmillan.

Bliss, Karina. 2012a. Bring Him Home. Special Forces 3. Toronto; New York: Harlequin.

- 2012b. Bring Him Home. Special Forces 3. Toronto; New York: Harlequin.

—. 2013. A Prior Engagement. Special Forces 4. Toronto ; New York: Harlequin.

\footnotetext{
${ }^{5} \mathrm{I}$ am grateful to a reviewer for this suggestion for further research.
} 
Brigg, Morgan, and Roland Bleiker. 2010. "Autoethnographic International Relations: Exploring the Self as a Source of Knowledge." Review of International Studies 36 (03): 779-98. doi:10.1017/S0260210510000689.

Carr, Robyn. 2012. The Virgin River Series. Reprint Edition. 20 vols. Harlequin.

Chelton, Mary K. 2015. "Readers' Advisory: There Seem to Be More SEALs in Romance Fiction than in the US Navy, and If So, Why Does It Matter?" Reference \& User Services Quarterly 55 (1): 21. doi:10.5860/rusq.55n1.21.

Connell, R. W., and James W. Messerschmidt. 2005. "Hegemonic Masculinity Rethinking the Concept." Gender \& Society 19 (6): 829-59. doi:10.1177/0891243205278639.

Crusie, Jennifer. 1997. "Romancing Reality: The Power of Romance Fiction to Reinforce and Re-Vision the Real." Paradoxa 1 (2): 81-93.

Dawson, Graham. 1994. Soldier Heroes: British Adventure, Empire, and the Imagining of Masculinities. Psychology Press.

Drezner, Daniel W. 2011. Theories of International Politics and Zombies. Princeton, N.J: Princeton University Press.

Dubino, Jeanne. 1993. "The Cinderella Complex: Romance Fiction, Patriarchy and Capitalism." The Journal of Popular Culture 27 (3): 103-18. doi:10.1111/j.0022-3840.1993.00103.x.

Duncanson, Claire. 2013. Forces for Good?: Military Masculinities and Peacebuilding in Afghanistan and Iraq. Houndmills, Basingstoke, Hampshire ; New York, NY: Palgrave Macmillan.

Elshtain, Jean Bethke. 1987. Women and War. University of Chicago Press.

Faircloth, Kelly. 2015. "How Harlequin Became the Most Famous Name in Romance.” Jezebel Pictorial. March 19. http://pictorial.jezebel.com/how-harlequin-became-the-mostfamous-name-in-romance-1692048963.

Faludi, Susan. 2008. The Terror Dream: Myth and Misogyny in an Insecure America. First Edition edition. New York: Picador.

Finley, Erin P. 2011. Fields of Combat: Understanding PTSD Among Veterans of Iraq and Afghanistan. Cornell University Press.

Fox, John, and Bob Pease. 2012. "Military Deployment, Masculinity and Trauma: Reviewing the Connections." The Journal of Men's Studies 20 (1): 16-31. doi:10.3149/jms.2001.16.

Frank, Arthur W. 2013. The Wounded Storyteller: Body, Illness, and Ethics, Second Edition. Second Edition edition. Chicago ; London: University Of Chicago Press. 
Frantz, Sarah S. G. 2002. “The Feminine Will to Power.” In Scorned Literature: Essays on the History and Criticism of Popular Mass-Produced Fiction in America, edited by Lydia Cushman Schurman and Deirdre Johnson, 17-36. Westport, Conn.: Greenwood Pub Group.

—. 2011. “'I've Tried My Entire Life to Be a Good Man': Suzanne Brockmann's Sam Starrett, Ideal Romance Hero." In Women Constructing Men: Female Novelists and Their Male Characters, 1750-2000, edited by Sarah S. G. Frantz and Katharina Rennhak, Reprint edition, 227-47. Lanham: Lexington Books.

Higate, Paul. 2012. "Drinking Vodka from the 'Butt-Crack."' International Feminist Journal of Politics 14 (4): 450-69. doi:10.1080/14616742.2012.726092.

Higgins, Kristan. 2013. The Best Man. Don Mills, Ontario: Harlequin.

Hoganson, Kristin L. 2000. Fighting for American Manhood: How Gender Politics Provoked the Spanish-American and Philippine-American Wars. Yale University Press.

Holden, Stacey E., and Charity Tabol. 2015. "In Sickness and In Health: Representations of PTSD in Post-9/11 Romance Novels.” Albeit. 2 (1). http://albeitjournal.com/in-sicknessand-in-health-representations-of-ptsd-in-post-911-romance-novels/.

Howell, Alison. 2011. Madness in International Relations: Psychology, Security, and the Global Governance of Mental Health. 1 edition. Abingdon, Oxon: Routledge.

Jarmakani, Amira. 2015. An Imperialist Love Story: Desert Romances and the War on Terror. NYU Press.

Jauregui, Beatrice. 2015. "World Fitness: US Army Family Humanism and the Positive Science of Persistent War." Public Culture 27 (3 77): 449-85. doi:10.1215/08992363-2896183.

Kamble, Jayashree. 2008. "Uncovering and Recovering the Popular Romance Novel.” University of Minnesota.

http://conservancy.umn.edu/bitstream/47092/1/Kamble_umn_0130E_10108.pdf.

—. 2012. "Patriotism, Passion, and PTSD: The Critique of War in Popular Romance Fiction." In New Approaches to Popular Romance Fiction: Critical Essays, edited by Sarah S. G. Frantz and Eric Murphy Selinger. Jefferson, N.C: McFarland \& Company.

Knox, Ruthie. 2013. Along Came Trouble. Camelot Series 2. New York: Loveswept.

Kronsell, Annica. 2006. "Methods for Studying Silences: Gender Analysis in Institutions of Hegemonic Masculinity." In Feminist Methodologies for International Relations, edited by Brooke Ackerly, Maria Stern, and Jacqui True, 108-27. Cambridge: Cambridge University Press. http://www.cambridge.org/gb/knowledge/isbn/item1162874/?site_locale=en_GB. 
Litte, Jane. 2011. "Unpacking the Navy SEAL Hero in Romance or the Magic in 'Let Me Take Care of You."” Dear Author. May 10. http://dearauthor.com/features/letters-ofopinion/unpacking-the-navy-seal-hero-in-romance-or-the-magic-in-let-me-take-care-ofyou/.

Lois, Jennifer, and Joanna Gregson. 2015. "Sneers and Leers Romance Writers and Gendered Sexual Stigma." Gender \& Society 29 (4): 459-83. doi:10.1177/0891243215584603.

Mallery, Susan. 2013. Three Little Words. A Fool's Gold Romance 12. Don Mills, Ontario: Harlequin.

Milliot, Jim. 2015. “The Hottest (and Coldest) Book Categories of 2014.” PublishersWeekly.com. January 23. http://www.publishersweekly.com/pw/bytopic/industry-news/bookselling/article/65387-the-hot-and-cold-categories-of-2014.html.

Park-Kang, Sungju. 2014. "Fictional IR and Imagination: Advancing Narrative Approaches." Review of International Studies 41 (2): 1-21. doi:http://dx.doi.org/10.1017/S0260210514000291.

Potter, Jane. 2008. Boys in Khaki, Girls in Print: Women's Literary Responses to the Great War 1914-1918. Oxford University Press.

Radway, Janice A. 1984. Reading the Romance: Women, Patriarchy, and Popular Literature. University of North Carolina Press.

Regis, Pamela. 2003. A Natural History of the Romance Novel. University of Pennsylvania Press. 2011. "What Do Critics Owe the Romance? Keynote Address at the Second Annual Conference of the International Association for the Study of Popular Romance." Journal of Popular Romance Studies 2 (1). http://jprstudies.org/2011/10/\%E2\%80\%9Cwhat-docritics-owe-the-romance-keynote-address-at-the-second-annual-conference-of-theinternational-association-for-the-study-of-popular-romance\%E2\%80\%9D-by-pamelaregis/.

Richland, Anna. 2014. His Road Home. Carina Press. http://rbdigital.oneclickdigital.com.

Romance Writers of America. n.d. "Romance Industry Statistics." Romance Writers of America. http://www.rwa.org/p/cm/ld/fid=580.

Ruderman, Zoe. 2011. "5 Reasons We Love Navy SEALs.” Cosmopolitan. http://www.cosmopolitan.com/sex-love/dating-advice/why-we-love-navy-seals.

Scott, Jessica. 2014a. All for You. Coming Home 2. Forever. 2014b. Back to You. Coming Home 1. Forever.

_ 2016. “About Jess.” Jessica Scott - Author. Accessed April 14. http://www.jessicascott.net/about-jess.html. 
Shalvis, Jill. 2012. Rescue My Heart. Berkley Sensation mass-market ed. Animal Magnetism 3. New York: Berkley Publishing Group.

- 2013. Rumor Has It. Berkley mass-market edition. New York, New York: Berkley Books.

- 2014. Once in a Lifetime. 1st ed. New York: Grand Central Pub.

Shepherd, Laura J. 2012. Gender, Violence and Popular Culture: Telling Stories. Oxon ; New York: Routledge.

Shin, Annys. 2011. "SEALs Go from Superhero to Sex Symbol." The Washington Post, May 10, sec. Local. http://www.washingtonpost.com/local/seals-go-from-superhero-to-sexsymbol/2011/05/04/AFCuNgAG_story.html.

Sjoberg, Laura, and Caron E. Gentry. 2007. Mothers, Monsters, Whores: Women's Violence in Global Politics. Zed Books.

Sylvester, Christine. 2012. War as Experience: Contributions from International Relations and Feminist Analysis. Milton Park, Abingdon, Oxon; New York, NY: Routledge.

Vivanco, Laura. 2011. For Love and Money: The Literary Art of the Harlequin Mills \& Boon Romance. Genre Fiction Monographs. Penrith: Humanities - Ebooks.

. 2013. For Love and Money. Humanities-Ebooks.

- 2016. Pursuing Happiness: Reading American Romance as Political Fiction. Humanities-Ebooks.

Weber, Cynthia. 2005. Imagining America at War: Morality, Politics and Film. 1 edition. Oxfordshire; New York: Routledge.

Wendell, Sarah, and Candy Tan. 2009. Beyond Heaving Bosoms: The Smart Bitches' Guide to Romance Novels. Original edition. New York: Touchstone.

Whitworth, Sandra. 2008. "Militarized Masculinity and Post-Traumatic Stress Disorder." In Rethinking the Man Question: Sex, Gender and Violence in International Relations, edited by Jane L. Parpart and Marysia Zalewski. Zed Books.

Wibben, Annick T. R. 2011. Feminist Security Studies: A Narrative Approach. 1 edition. London; New York: Routledge.

Woolf, Adam Gregory. 2012. "Competing Narratives: Hero and PTSD Stories Told by Male Veterans Returning Home." University of South Florida. http://scholarcommons.usf.edu/etd/4260/.

"Write for Us: Harlequin Superromance." n.d. Harlequin. http://www.harlequin.com/articlepage.html?articleId=834\&chapter=0. 
